\title{
Seasonal and spatial distribution of glomalin-related soil protein and sequestered metals affected by AM fungi in the citrus rizosphere
}

\begin{abstract}
In a controlled pot experiment, Poncirus trifoliate and Citrus reticulate seedlings were inoculated with arbuscular mycorrhizal (AM) fungi, Glomus epigaeum. Seasonal (June, September, December and March) and spatial distribution $(0-2 \mathrm{~cm}, 2-4 \mathrm{~cm}$ and $4-8 \mathrm{~cm}$ away from the taproot in horizon) of glomalin-related soil protein (GRSP) and sequestered heavy metals were studied. The results showed that the hyphal length was in the following order $0-2 \mathrm{~cm}>2-4 \mathrm{~cm}>4-8 \mathrm{~cm}$ in horizontal distribution, which was the highest in March, lowest in December. The easily extractable Bradford-reactive soil protein (EE-BRSP) and total Bradford-reactive soil protein (T-BRSP) arranged between $1.0-2.6 \mathrm{mg} \mathrm{g}^{-1}$ and $2.0-5.8 \mathrm{mg} \mathrm{g}^{-1} \mathrm{DW}$ soil in the biosphere of $P$. trifoliate, $1.3-2.5 \mathrm{mg} \mathrm{g}^{-1}$ and $2.5-5.0 \mathrm{mg} \mathrm{g}^{-1} \mathrm{DW}$ soil in C.reticulate. Both EE-BRSP and T-BRSP in June were significantly higher than those in December. However, the two BRSPs did not decrease with the extension of distance in horizon $(0-8 \mathrm{~cm})$, but ranked at 2-4 $\mathrm{cm}>4-8 \mathrm{~cm}>0-2 \mathrm{~cm}$. The amounts of Fe bound to GRSP varied between $5.11 \mathrm{mg} \mathrm{g}^{-1} \mathrm{DW}$ to $9.20 \mathrm{mg} \mathrm{g}^{-1}$ DW GRSP, and Mn 76.28-244.48ugg ${ }^{-1}$ DW GRSP, Cu 18.11-91.00ugg ${ }^{-1}$ DW GRSP, and Zn 62.97-315.83 ugg $^{-1}$ DW GRSP. All the heavy metals (HMs) bound to GRSP were highest in June, lowest in December. In horizontal distribution, those HMs were followed by $2-4 \mathrm{~cm}>4-8 \mathrm{~cm}>0-2 \mathrm{~cm}$, consistent with EE-BRSP and T-BRSP. Our results demonstrated that the seasonal and spatial distribution of GRSP is significantly different in horizontal soil.
\end{abstract}

Keywords: seasonal and spatial distribution, glomalin-related, soil protein, heavy metals, citrus, glomus epigaeum
Volume 6 Issue 6 - 2017

\author{
Mingyuan Wang,' Jianfu Liu,' Wensheng Lai ${ }^{2}$ \\ 'Department of Horticulture, Huaqiao University, China \\ ${ }^{2}$ Forest Seed and Seedling General Station of Fujian Province, \\ China
}

Correspondence: Mingyuan Wang, Department of Horticulture, No.668, jimei Avenue, Huaqiao University, Xiamen 36102I, China, Tel +865-926-162-300, Fax +865-926-162-300, Email mywang@hqu.edu.cn

Received: December 09, 2016 | Published: April 04, 2017
Abbreviations: AM, arbuscular mycorrhizal; GRSP, glomalinrelated soil protein; EE-BRSP, easily extractable bradford-reactive soil protein; HMs, heavy metals; T-BRSP, total bradford-reactive soil protein

\section{Introduction}

Glomalin, produced by arbuscular mycorrhizal (AM) fungi, exists in most soil ecosystem and is quantified as glomalin-related soil protein $(\mathrm{GRSP})^{1,2}$ which contains two kinds of protein, easily extractable BRSP (EE-BRSP) and total BRSP (T-BRSP). It is reported that GRSP may influence soil fertility due to its complex with 0.04 $8.8 \%$ iron, ${ }^{3}$ remedy soil contamination by sequestering potentially toxic elements, such as $\mathrm{Zn}, \mathrm{Cu}, \mathrm{Cd}, \mathrm{Pb}^{4}$ and alleviate biotic and abiotic stresses. ${ }^{5,6} \mathrm{GRSP}$ has been suggested to be used as biological indicators of soil quality. ${ }^{2}$ However, as an alkaline-soluble protein material, the production of GRSP is affected by kinds of environmental factors, such as host plant species, and soil amendment and fertilizer, tillage., The distribution of GRSP in rhizospheric soil has been studied. Guo et al., ${ }^{9}$ thought the GRSP contents changed following the soil depth extension, and most of GRSP existed in $0-20 \mathrm{~cm}$ soil. Vasconcellos et al. ${ }^{10}$ found that the concentration of EE-BRSP and T-BRSP were strong related to the ages of recovery after reforestation in the Atlantic forest in Brazil. In general, most documents report the vertical and spatial distribution of GRSP in the soil. However, both the GRSP in vertical and horizontal distribution are important towards plants and land ecological system. To deep understanding the function of GRSP, it is necessary to evaluate the horizontal distribution in soil. Although
GRSP concentration was much different in different seasons, it was in tropical forest which was obviously different to terrestrial system. ${ }^{10}$

In China, trifoliate orange (Poncirustrifoliata L. Raf) and red tangerine (Citrus reticulata Blanco) are widely used as rootstocks in citrus orchards. ${ }^{11}$ In this paper, two-compartment systems in pot culture was set up, which citrus lateral roots in the main soil compartment was separated from by a nylon mesh that prevented penetration by roots but not fungal hyphae. The purpose is to explore the GRSP in horizontal distribution and how to vary following the season, helping to analyze the microenvironment which GRSP distributes and play function in the soil.

\section{Materials and methods}

\section{Experimental site, pot culture and mycorrhizal inoculum}

A glasshouse experiment was conducted in 2014 at Huaqiao University. The soil was from the vegetable land, which the basic physical-chemical characteristics were $\mathrm{pH} 4.63$, alkaline nitrogen $84.53 \mathrm{mg} \mathrm{kg}^{-1}$, available phosphorus $26.11 \mathrm{mg} \mathrm{kg}^{-1}$, available potassium $144.79 \mathrm{mg} \mathrm{kg}^{-1}$ and organic matter $54.60 \mathrm{~g} \mathrm{~kg}^{-1}$. The soil was autoclaved at $121^{\circ} \mathrm{C}, 0.11 \mathrm{MPa}$ for $2 \mathrm{~h}$, and cooled at room temperature, and then distributed into $17-\mathrm{cm}$-diameter plastic pots with $5.0 \mathrm{~kg}$ per pot.

Seeds of trifoliate orange ( $P$. trifoliate L. Raf) and red tangerine (C. reticulata Blanco) were surface-sterilized with $75 \%(\mathrm{v} / \mathrm{v})$ ethanol for $10 \mathrm{~min}$ and germinated on wet filter paper at $26^{\circ} \mathrm{C}$. Two weeks 
later, seedling was transplanted to a plastic pot containing $5 \mathrm{~kg}$ of above soil. Before sowing, two-compartment systems in pot culture were set up by nylon mesh bags. The nylon mesh bag was $4 \mathrm{~cm}$ in diameter and $20 \mathrm{~cm}$ in depth opening with one end. The AM fungus Glomus epigaeum was provided by the Institute of Plant Nutrition and Resources, Beijing Academy of Agriculture and Forestry Sciences. The soil was inoculated with 1488 spores and filled into the nylon mesh bags. One seedling was sown in the centre of each bag, which citrus lateral roots the main soil compartment was separated from by a nylon mesh that prevented penetration by roots but not fungal hyphae. Then, the bag with the seedling was put into the above pot which was full of sterilized soil.

\section{Experimental design}

Soil samples in $0-2 \mathrm{~cm}, 2-4 \mathrm{~cm}$ and $4-8 \mathrm{~cm}$ away from taproot of the host plant, were collected with punching bear on 15th in June, September, December in 2014 and March in 2015, respectively. The soil samples from six random pots were mixed and sub-sample was taken for determination of hyphal length, GRSP and HMs sequestered by GRSP.

\section{Determination of hyphal length}

Hyphal length was measured acoording to Bethlenfalvay et al. ${ }^{12}$ Approx. 1.0 to $1.5 \mathrm{~g}$ air dried soil was placed in $50 \mathrm{ml}$ of a $\mathrm{pH}$ 7.0 phosphate-buffered salt solution. The soil solution mixture was blended for $30 \mathrm{~s}$, and $1.0 \mathrm{ml}$ sample of this solution was placed in a centrifuge tube containing $0.5 \mathrm{ml}$ of $0.05 \%$ trypan blue. After water bath at $70^{\circ} \mathrm{C}$ for $20 \mathrm{~min}$, a known volume of the solution containing the hyphae was prepared on the slides. The slide containing sample solution was under a microscope and nine triplicates were observed for each soil sample. The hyphal length was calculated by knowing the volume of suspension within each slide, the volume of the original suspension and the dry weight of each soil sample.

\section{Analysis of GRSP and HMs sequestered by GRSP}

The GRSP including the easily extractable BRSP (EE-BRSP) and total BRSP (T-BRSP) was extracted by the Bradford method as Bradford-reactive soil proteins (BRSPs) ${ }^{13}$ Determination of the two BRSPs was carried out following Bedini et al. ${ }^{14}$ The GRSP content was extrapolated tomg $\mathrm{g}^{-1}$ dry weight of the soil samples. To determine HMs bound to GRSP, the method was followed González-Chávez et al. ${ }^{15}$ and the measurement following Bradford et al., ${ }^{16}$

\section{Statistical analyses}

Data were statistically tested by two-way analysis of variance (ANOVA) using the SAS version 8.1 software package (SAS Institute, Cary, NC). Probabilities of significance were used to test the significance among treatments, and least significant difference (LSD) $(P<0.05)$ was used to compare the means.

\section{Results and discussion}

\section{Varies of hyphal length}

Both the two citrus cultivars were colonized by AM fungi, but the hyphal length varied following the season and horizontal distance (Figure 1). The hyphal length ranked at September $>$ Mach $>$ June $>$ December. Significant difference was found between the ones in September and December $(P<0.05)$. In addition, the hyphal length was significantly higher in $0-2 \mathrm{~cm}$ soil compared to that in $4-8 \mathrm{~cm}$ soil in the same season $(P<0.05)$. The highest hyphal length was $0.68 \mathrm{~m} \mathrm{~g}^{-1}$ dry soil in P. trifoliate (Figure 1A), and $0.59 \mathrm{~m}$ $\mathrm{g}^{-1}$ dry soil in C.reticulate (Figure 1B). In horizon distribution, the hyphal length was highest in $0-2 \mathrm{~cm}$ soil, whereas it was the lowest in $4-8 \mathrm{~cm}$ soil. The results showed that hyphal length could be found in 4-8cm soil far away from the citrus taproot, which was in accord with the results of Steinberg et al. ${ }^{17}$ Furthermore, a clear decrease of hyphal length in the order of $0-2 \mathrm{~cm}>2-4 \mathrm{~cm}>4-8 \mathrm{~cm}$ in horizon emerged, suggesting that hyphal growth got more difficult following the distance away from the infection point.

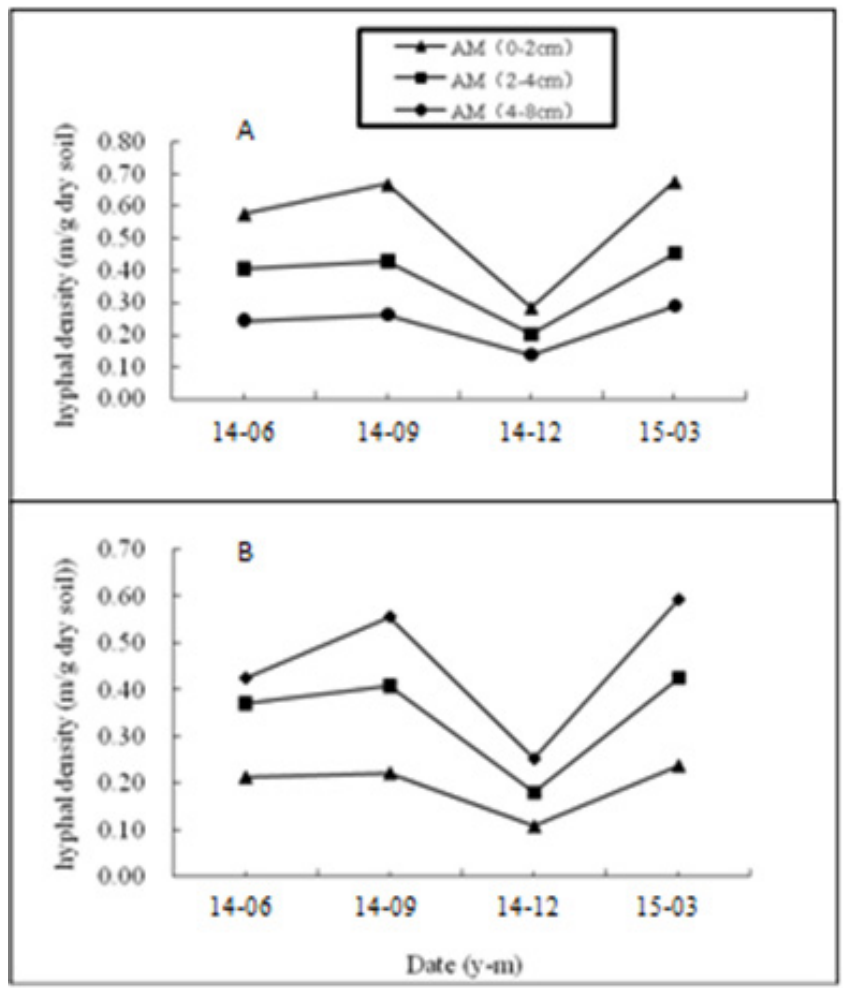

Figure I The hyphal length in the rhizosphere of Poncirus trifoliate $(A)$ and Citrus reticulate $(B)$. Data are expressed as means $(n=6)$.

Few studies have examined the seasonality of external hyphae in pot culture. In general, the abundance of AM hyphae fluctuates in one season of the host plants growth, because of mycorrhizal obligate symbiont with live plants. Treseder et al., ${ }^{18}$ found the production and turnover of fungal hyphae was at low rates throughout the dry season, but no significant difference. Our experiment results were in accordance with the former research. The hyphal length was lowest in December, highest in March. It was likely that plants were under severe temperature stress, and the carbon allocation from plant to fungus decreased. As a consequence, hyphal growth was limited due to lack of enough nutrition. ${ }^{19}$ Subramanian et al. ${ }^{20}$ also reported that soil organic carbon could not build up under the temperature stress.

\section{Analysis of EE-GRSP and T-GRSP}

EE-GRSP concentration of both $P$. trifoliate and C.reticulate in different rhizosphere were higher in June and Mach, lower in December. The maximum was present in June $\left(2.58 \mathrm{mg} \mathrm{g}^{-1} \mathrm{DW}\right.$ soil in P. trifoliate and $2.57 \mathrm{mg} \mathrm{g}^{-1} \mathrm{DW}$ soil in C.reticulate), significantly higher than those in December which showed the minimum $(1.31 \mathrm{mg}$ $\mathrm{g}^{-1} \mathrm{DW}$ soil in P. trifoliate and $1.02 \mathrm{mg} \mathrm{g}^{-1} \mathrm{DW}$ soil in C.reticulate) 
$(P<0.05)$ (Figure 2A) (Figure 3A). In horizontal soil, the EE-GRSP ranked at $2-4 \mathrm{~cm}>4-8 \mathrm{~cm}>0-2 \mathrm{~cm}$ in rhizosphere of both the two citrus. However, no significant difference between the ones in $2-4 \mathrm{~cm}$ and $4-8 \mathrm{~cm}$ and $0-2 \mathrm{~cm}$ soil within the same season. T-GRSP contents of both $P$. trifoliate and C. reticulate in rhizosphere were followed by June $>$ Mach $>$ September $>$ December, and the maximum was present in June $\left(5.76 \mathrm{mg} \mathrm{g}^{-1} \mathrm{DW}\right.$ soil in P. trifoliate and $4.98 \mathrm{mg} \mathrm{g}^{-1} \mathrm{DW}$ soil in C.reticulate), significantly higher than those in December $(2.03 \mathrm{mg}$ $\mathrm{g}^{-1}$ DW soil in $P$. trifoliate and $2.45 \mathrm{mg} \mathrm{g}^{-1} \mathrm{DW}$ soil in C.reticulate) $(P<0.05)$ (Figure 2B) (Figure 3B). In horizontal soil, the T-GRSP ranked at $2-4 \mathrm{~cm}>4-8 \mathrm{~cm}>0-2 \mathrm{~cm}$ in both the two citrus species. However, no significant difference was found between the ones at $2-4 \mathrm{~cm}$ and $4-8 \mathrm{~cm}$ and $0-2 \mathrm{~cm}$ soil in the same season. Actually, a range of $1.02-2.658 \mathrm{mg} \mathrm{g}^{-1}$ DW soil EE-BRSP in the citrus rhizosphere was lower than those (3.87-3.94 $\mathrm{mg} \mathrm{g}^{-1}$ ) in Manawatu and Ngamoko grass in New Zealand. ${ }^{21}$ In addition, a range of $2.03-5.76 \mathrm{mg} \mathrm{g}^{-1} \mathrm{DW}$ soil T-BRSP was also lower compared with that in grassland soils (9.3$2.0 \mathrm{mg} \mathrm{g}^{-1} \mathrm{DW}$ soil, $\left.{ }^{14}\right)$, but higher than Otindag sandy land, China (0.26-0.93 $\mathrm{mg} \mathrm{g}^{-1}$ DW soil, ${ }^{9}$ This may be due to different AM fungi species and the different soil management. ${ }^{7}$

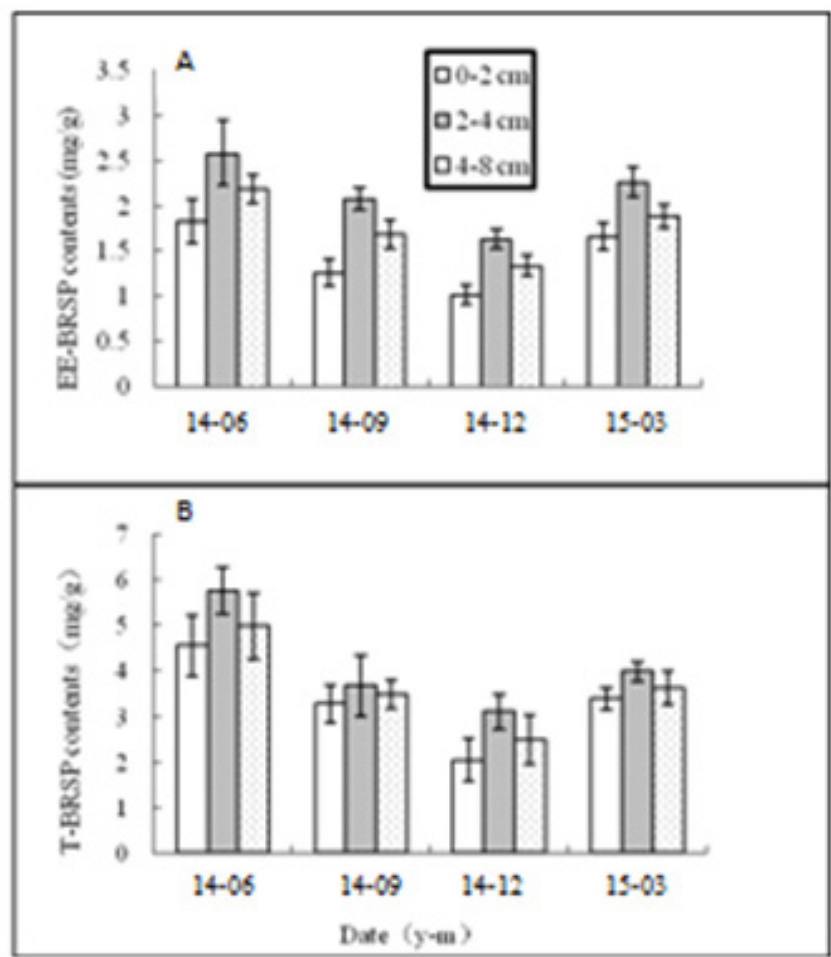

Figure 2 Contents of easily extractable Bradford-reactive soil protein (EE-BRSP) (A) and total Bradford-reactive soil protein (T-BRSP) (B) in the rhizosphere of Poncirus trifoliate. Data are expressed as means $(n=6)$.

Both the two BRSPs were higher in March and June, lower in September and December, which was consistent with the changes in hyphal length. Generally, about $80 \%$ of glomalin produced by the AM fungus was contained in hyphae and spores, and $20 \%$ of those were from release by hyphae, not through secretion. ${ }^{22}$ It was not surprised that EE-BRSP and T-BRSP could be found up to $4-8 \mathrm{~cm}$ soil range. The soil EE-BRSP and T-BRSP contents in both the two citrus rootstocks were the lowest in $0-2 \mathrm{~cm}$ soil range in horizon, compared to $2-4 \mathrm{~cm}$ and $4-8 \mathrm{~cm}$ soil range. It seemed that the two BRSPs contents did not follow the gradient $0-2 \mathrm{~cm}>2-4 \mathrm{~cm}>4-8 \mathrm{~cm}$. It has been reported that climate, vegetation type and productivity, soil mineralogy, and fungal species and diversity might determine why there are differences in concentration of soil glomalin across sites. ${ }^{23}$

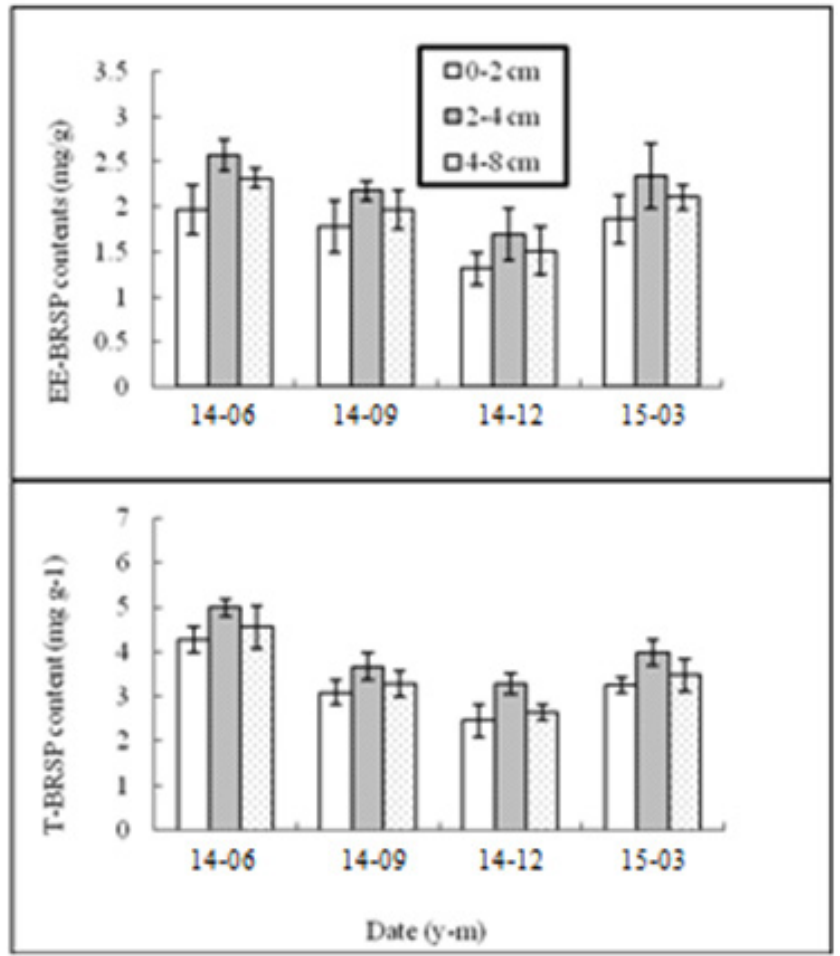

Figure 3 Contents of easily extractable Bradford-reactive soil protein (EE-BRSP) (A) and total Bradford-reactive soil protein (T-BRSP) (B) in the rhizosphere of Citrus reticulate. Data are expressed as means $(n=6)$.

In additional, soil $\mathrm{C}$ and $\mathrm{N}$ pools affected BRSP significantly. Lovelock et al., ${ }^{24}$ thought glomalin was a significant component of total soil $\mathrm{C}(3.2 \%)$ and $\mathrm{N}(5 \%)$ pools in the surface layer. The $0-2 \mathrm{~cm}$ soil in horizon might contain less soil $\mathrm{C}$ pools due to the uptake by citrus, compared to $2-4 \mathrm{~cm}$ and $4-8 \mathrm{~cm}$ soil. Additionally, the EE-BRSP and T-BRSP might decompose too much because of the amounts of microorganisms in the $0-2 \mathrm{~cm}$ soil.

\section{Concentration of the HMs sequestered by GRSP}

$\mathrm{HMs}(\mathrm{Fe}, \mathrm{Mn}, \mathrm{Cu}$ and $\mathrm{Zn}$ ) bound to GRSP in the rhizosphere of both two citrus species were showed in Figure 4 and Figure 5. The Fe content varied from $6.03-8.88 \mathrm{mgg}^{-1}$, and $\mathrm{Mn} 76.28-202.57 \mathrm{ugg}^{-1}, \mathrm{Cu}$ 25.51-88.14ugg-1 and Zn 62.97-297.03 ugg $^{-1}$ in P. trifoliate. The HMs contents in June were significantly higher than those in December $(P<0.05)$. In the same season, the HMs bound to GRSP ranked at $2-4 \mathrm{~cm}>4-8 \mathrm{~cm}>0-2 \mathrm{~cm}$ in horizontal distribution (Figure 4). The $\mathrm{Fe}$ content varied from 5.11-9.20 $\mathrm{mgg}^{-1}$, and $\mathrm{Mn} 86.60-244.48 \mathrm{ugg}^{-1}, \mathrm{Cu}$ 18.11-91 ugg $^{-1}$ and $\mathrm{Zn} 80.36-315.83$ ugg $^{-1}$ in C. reticulate. The changes in horizonal distribution were consistent with that in $P$. trifoliate (Figure 5).

Many reports have been shown that heavy metals $(\mathrm{HMs})(\mathrm{Cu}, \mathrm{Cd}$, $\mathrm{Pb}$ and so on) can be absorbed and accumulated in host plants with the help of AM fungi. ${ }^{25,26}$ One of the most important factors is GRSP, which binds HMs to avoid the HMs toxicity on soil environment. ${ }^{27}$ In this study, $\mathrm{Fe}, \mathrm{Cu}, \mathrm{Mn}$ and $\mathrm{Zn}$ bound to GRSP were higher in June and March, and lower in December. Thus, the changes in seasonal and horizontal distribution were consistent with the ones of GRSP, suggesting that GRSP had a fair capacity for HMs. A range of 5.11- 
9.20 $\mathrm{mg} \mathrm{g}^{-1}$ of Fe and 76.28-244.48ug g $\mathrm{g}^{-1}$ of Mn bound to BRSP was comparable with that in Devon Consol Mines, England, ${ }^{15}$ and a range of 18.11-91.00ug g $\mathrm{u}^{-1}$ of $\mathrm{Cu}$ and 18.11-91.00ug $\mathrm{g}^{-1}$ of $\mathrm{Zn}$ bound to BRSP was comparable with that in Mediterranean ecosystem. ${ }^{28}$ AM fungus could alleviate the toxicity of HMs to host plant, not only by colonized roots, but also by the hyphae and the glomalin in soil.

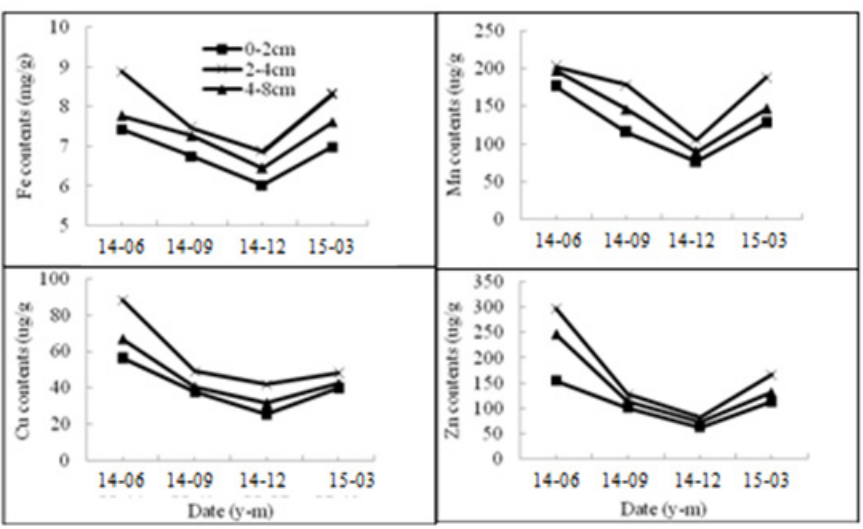

Figure 4 The amount of $\mathrm{Fe}, \mathrm{Cu}, \mathrm{Mn}$ and $\mathrm{Zn}$ bound to GRSP in the rhizosphere of Poncirus trifoliate. Data are expressed as means $(n=6)$.

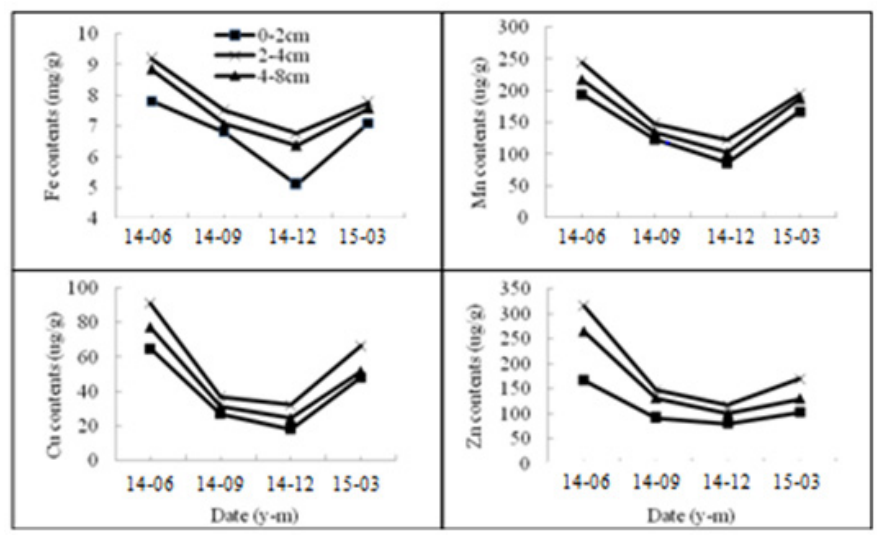

Figure 5 The amount of $\mathrm{Fe}, \mathrm{Cu}, \mathrm{Mn}$ and $\mathrm{Zn}$ bound to GRSP in the rhizosphere of Citrus reticulate. Data are expressed as means $(n=6)$.

\section{Conclusion}

The hyphal length changed following the season and ranked at September $>$ Mach $>$ June $>$ December in a year. The distribution of EE-GRSP and T-GRSP were affected significantly by AM fungi, Glomus epigaeum. The concentration were following at 2-4 $\mathrm{cm}>4-8$ $\mathrm{cm}>0-2 \mathrm{~cm}$ in horizontal soil in both the two citrus species. The HMs bound to GRSP were comparable with the documents reported, and the seasonal changes were consistent with the GRSP.

\section{Acknowledgements}

The work was supported by the National Natural Science Foundation of China (No. 31101512), Special Project on Education and Research of Fujian Province (No. 2017N5009), and Research Funds of Fujian forestry Science (Z1425063/3).

\section{Conflict of interest}

All authors declare that no any conflict of interest exists.

\section{References}

1. Wright SF, Nichols KA, Schmidt WF. Comparison of efficacy of three extractants to solubilize glomalin on hyphae and in soil. Chemosphere. 2006;64:1219-1224.

2. Fokom R, Adamou S, Teugwa MC, et al. Glomalin related soil protein, carbon, nitrogen and soil aggregate stability as affected by land use variation in the humid forest zone of south Cameroon. Soil Till Res. 2012;120:69-75.

3. Nichols KA, Wright SF. Comparison of glomalin and humic acid in eight native US soils. Soil Sci. 2005;170:985-997.

4. Miransari M. Contribution of arbuscular mycorrhizal symbiosis to plant growth under different types of soil stress. Plant Biol. 2010;12:563-569.

5. Kohler J, Caravaca F, Roldán A. An AM fungus and a PGPR intensify the adverse effects of salinity on the stability of rhizosphere soil aggregates of Lactuca sativa. Soil Bio Biochem. 2010;42:429-434.

6. Cui XC, Hu JL, Lin XG, et al. Arbuscular mycorrhizal fungi alleviate ozone stress on nitrogen nutrition of field wheat. J Agr Sci tech-Iran. 2013;15:1043-1052.

7. Wang P, Liu JH, Xia RX, et al. Arbuscular mycorrhizal development, glomalin-related soil protein (GRSP) content, and rhizospheric phosphatase activity in citrus orchards under different types of soil management. J Plant Nutr Soil Sci. 2011;174:65-72.

8. Zhang XK, Wu X, Zhang SX, et al. Organic amendment effects on aggregate-associated organic $\mathrm{C}$, microbial biomass $\mathrm{C}$ and glomalin in agricultural soils. Catena. 2014;123:188-194.

9. Guo HJ, He XL, Li YP. Spatial distribution of arbuscular mycorrhiza and glomalin in the rhizosphere of Caragana korshinskii Kom. in the Otindag sandy land, China. Afr J Microbiol Res. 2012;6:5745-5753.

10. Vasconcellos RLF, Bonfim JA, Baretta D, et al. Arbuscular mycorrhizal fungi and glomalin-related soil protein as potential indicators of soil quality in a recuperation gradient of the atlantic forest in Brazil. Land Degrad. Develop. 2016;27:325-334.

11. Wang MY, Xia RX, Dong T, et al. Arbuscular mycorrhizal fungi alleviate iron deficient chlorosis inP.trifoliataL. Raf under calcium bicarbonate stress. J Hort Sci Biotech. 2007;82:776-780.

12. Bethlenfalvay GJ, Ames RN. Comparison of two methods for quantifying extra-radical hyphal of vesicular-arbuscular mycorrhizal fungi. Soil Sci Soc Am J. 1987;51:834-837.

13. Rosier CL, Hoye AT, Rillig MC. Glomalin-related soil protein:assessment of current detection and quantification tools. Soil Bio Biochem. 2006;38:2205-2211.

14. Bedini S, Pellegrino E, Avio L, et al. Changes in soil aggregation and glomalin-related soil protein content asaffect by the arbuscular mycorrhizal fungi species Glomus mosseae and Glomusintraradices. Soil Biol Biochem. 2009;41:1491-1496.

15. González-Chávez MC, González-Carrillo R, et al. The role of glomalin, a protein produced by arbuscular mycorrhizal fungi,in sequestering potentially toxic elements. Environ Pollut. 2004;130:317-323.

16. Bradford GR, Page AL, Lund JL, et al. Trace element concentrations of sewage treatment plants available lead, cadmium and molybdenum in mine tailings and contaminated soils. Madison, Wisconsin: Agronomy Society of America; 1975.

17. Steinberg PD, Rillig MC. Differential decomposition of arbuscular mycorrhizal fungal hyphae and glomalin. Soil Bio Biochem. 2003;35:191194. 
18. Treseder KK, Schimel JP, Garcia MO, et al. Slow turnover and production of fungal hyphae during a Californian dry season. Soil Bio Biochem. 2010;42:1657-1660.

19. Smith SE, Read DJ. Mycorrhizal Symbiosis. San Diego, CA: Academic Press; 1997.

20. Subramanian KS, Tenshia V, Jayalakshmi K, et al. Biochemical changes and zinc fractions in arbuscular mycorrhizal fungus (Glomus intraradices) inoculated and uninoculated soils under differential zinc fertilization. Appl Soil Ecol. 2009;43:32-39.

21. Rillig MC, Hoye AT, Carran A. Minimal direct contribution of arbuscularmycorrhizal fungi to DOC leaching in grassland through losses of glomalin related soil protein. Soil Biol Biochem. 2006;38:2967-2970.

22. Driver JD, Holben WE, Rillig MC. Characterization of glomalin as a hyphal wall component of arbuscular mycorrhizal fungi. Soil Bio Biochem. 2005;37:101-106.

23. Wu QS, Li Y, Zou YN, et al. Arbuscular mycorrhiza mediates glomalin-related soil protein production and soil enzyme activities in the rhizosphere of trifoliate orange grown under different P levels. Mycorrhiza. 2015;25(2):121-130.
24. Lovelock CE, Wright SF, Nichols KA. Soil stocks of glomalin produced by arbuscular mycorrhizal fungi across a tropical rain forest landscape. $J$ Ecol. 2004;92:278-287.

25. Vodnick D, Grčmana H, Mačeka I, et al. The contribution of glomalinrelated soil protein to $\mathrm{Pb}$ and $\mathrm{Zn}$ sequestration in polluted soil. Sci Total Environ. 2008;392:130-136.

26. Aguilera P, Borie F, Seguel A, et al. Fluorescence detection of aluminum in arbuscular mycorrhizal fungal structures and glomalin by using confocal laser scanning microscopy. Soil Biol Biochem. 2011;43:2417-2431.

27. Gil-Cardeza ML, Ferri A, Cornejo P, et al. Distribution of chromium species in a $\mathrm{Cr}$ polluted soil: Presence of $\mathrm{Cr}$ (III) in glomalin related protein fraction. Sci Total Environ. 2014;493: 828-833.

28. Cornejo P, Meier S, Borie G, et al. Glomalin-related soil protein in a Mediterranean ecosystem affected by a copper smelter and its contribution to $\mathrm{Cu}$ and $\mathrm{Zn}$ sequestration. Sci Total Environ. 2008;406(1-2):154-160. 